\title{
Environmental design feature
}

\section{JÓZEF FLIZIKOWSKI *}

Prof. dr hab. inż. Józef Flizikowski, fliz@utp.edu.pl, https://orcid.org/0000-0001-7264-7776 - Instytut Technik Wytwarzania, Wydział Inżynierii Mechanicznej UTP w Bydgoszczy, Polska

The purpose of the study is to identify the need to address the environmental, usability and harmfulness of the structure (design), the rational development of the essence of the fourth design feature of machine components, equipment and other engineering and technical facilities as well as the environment. Known to the designers of machine construction and technology, three design features are commonly used: geometric, material and dynamic, oriented on the form, dimension and tolerance of the outer form, internal structure and the assembly capabilities of the design elements. The development of technology indicates the possibility of expending the concept of three design features, along with an environmental characteristic, as the root causes, functional and secondary existence of machinery, equipment, installation, also the environment. The aim of the study was achieved, indicating environmental useful values of the structure, in the proposal for a general outline of the essence of the fourth design feature of machine components, equipment and other engineering and technical facilities, on the example of turbine blades of windmills.

KEYWORDS: machine design, environment, resources, potential for action, harmlessness

\section{Introduction}

Despite the huge number of publications on construction, entries in encyclopaedias (over 70,000 in 2002) [5] and electronic sources (61.9 million matching Google search results in 2019) related directly or indirectly to the construction, no-one can judge what is definitely a construction and what is not. Many specialists in the field of mechanics, machine construction (mechanical engineering), computer science and partly architecture consider it as abstraction. Definition of a construction understood as concrete has equally many followers. It can be assumed that it is a set of elements of the object connected together in a functionally purposeful whole or a set of features defining a purposely constructed object or its part $[2,4-6,14,18-20]$.

Technical, economic, ecological and manufacturing possibilities of the construction are based on the constructor's reasons - so strongly connected with common sense.

The aim of the study is to try to find the answer to the question: how to reasonably choose construction features (properties) to minimize environmental damage, i.e. meet the criteria for limiting the consumption of natural resources and limiting emissions (minimizing harmfulness). This would be very valuable knowledge, but by design, when choosing technical features of technical system, and then introducing this technical system into the environment, we change the design of the environment, and technical system takes on the features of the environment, etc. Is there no need to address the environmental design feature?

There are more questions, and an attempt to answer one of them - about the environmental, fourth structural feature - although in part, was undertaken in this study.

\section{Three features are not enough}

Structure of the scientific system of construction since Aristotle's time is modeled on mathematics and leads to a specific end result (fig. 1). It covers division of sentences of scientific theory into premises, assumptions and theorems reliably inferred from them, according to a clear or intuitive structure.

Construction potential is the essence of change, it is what it can be - become in the future - the state and permissible changes in technical conditions ( $T_{\mathrm{C}}$, measures, methods, activities) necessary for the occurrence of the postulated state $(P S)$ : the occurrence of value (product quality, process efficiency, product and process 
harmlessness). For example: wind turbine blades have a specific construction, according to which they are made of composites; textile reinforcements are wound on the core, fillers and specialized surface coatings are applied. The process effectiveness is analysed, assessed and developed in three aspects: ecology, economy and energy.

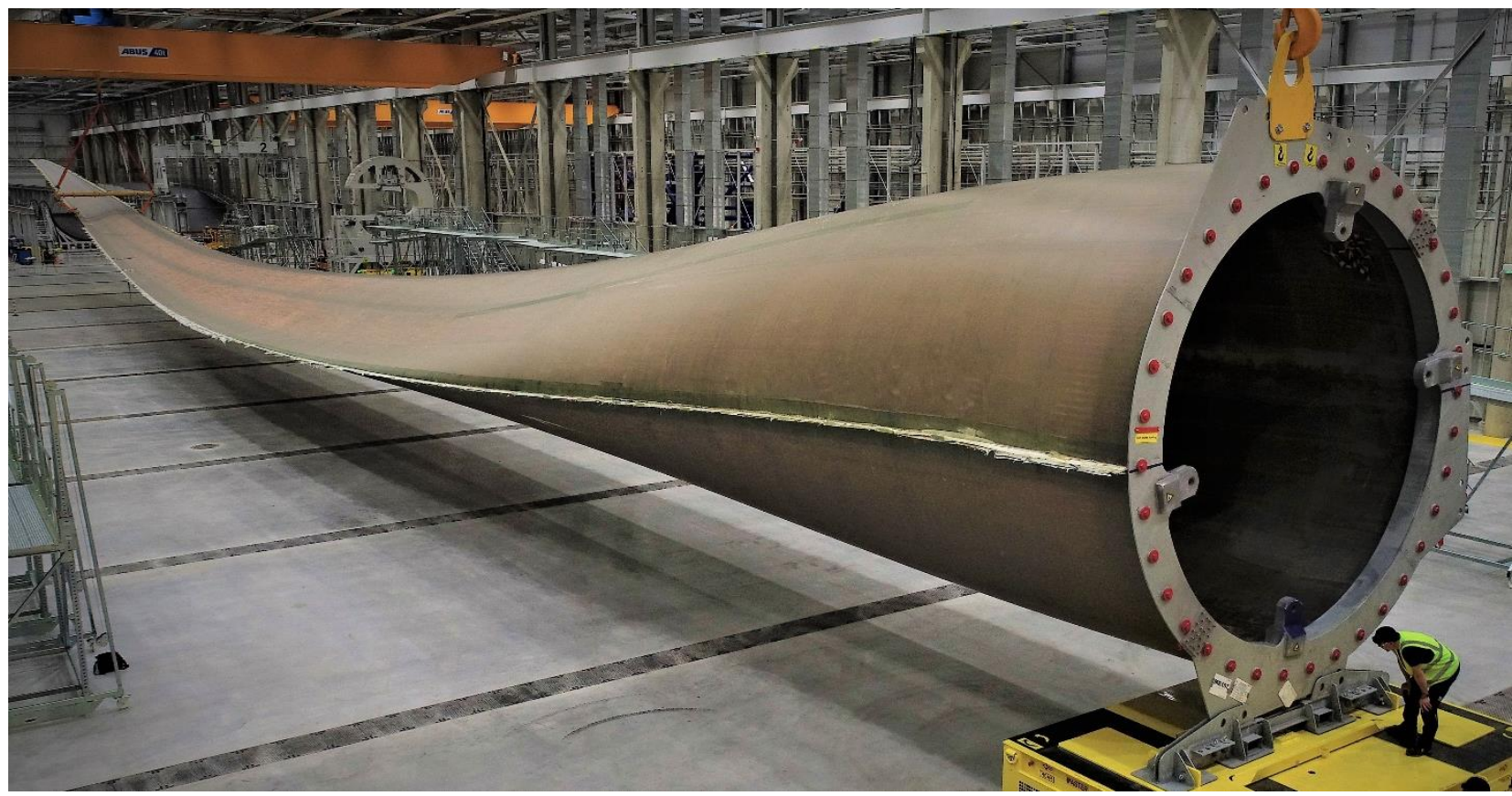

Fig. 1. The effect of the process of forming a $107 \mathrm{~m} 12 \mathrm{MW}$ wind turbine blade, LM factory in Cherbourg, France, project manager MSc. Łukasz Cejrowski (graduate of WIM UTP, Bydgoszcz) [21]

There are four reasons for the existence of engineering and technical construction and the environment, and their movement (after Aristotle): material, formal, efficient and purposeful. Although the very beginning, there is substance and essence, because why a construction will be created, it will be exploited and liquidated, depends on its creator, the reason and principles of its creation. The matter (material, construction material), from which it is made, is the first reason for the existence of a structure. The form, shape, geometric form (element, sub-assembly, construction unit and the whole machine), which should be given to matter, is the second reason for the existence of the structure. The third is the first movement, assembly, the beginning of idle, working (material form) movement, causing activities, objects, products, services. The fourth reason (of the moving material form) is the purpose of action, good, material, economic, ecological values that can be achieved through the operation of the structure, because - as Aristotle [5] said - good (reproducible, non-playable, products, services) is the cause of all creation and movement.

What is the end of engineering and technical construction: what happens to a machine structural element, the features of which lose their limit values? As we know, such an element had three design features [1-6, 13, 14, 18-20]: geometric, material and dynamic, and these had three characteristics: form, dimensions and tolerance. Each substance, cause, and feature has a certain limit, which when exceeded means that the element's structure ceases to be what it is - it loses its essential features. The change of acceptable forms, dimensions, tolerances of geometric features causes the structural element to turn into waste. Similar consequences are exceeding the allowable (and even only optimal) forms, dimensions and tolerances of material and dynamic features.

Is the construction of environment governed by reasons other than engineering and technical construction? Here, too, a change in the permissible forms, dimensions, tolerance of geometric features of raw material resources (material, energy, information) leads to an end, causes the resource to deform, and, for example, nonplayable one - to disappear. Exceeding the allowable (in the optimal environment) forms, dimensions and tolerances of material and dynamic features causes destruction or devastation of the resources of reproducible and unplayable goods. And it is difficult to talk about waste here, because we live in what remains after deformation, destruction and devastation!

Since primary goods (reproducible, unreproducible) and secondary goods (products, services) are the cause of all arising and movement, then the path of the product's creator includes machine, building and environmental constructions - resources, potentials and harmfulness (emissions, consequences, waste). 
This path is based on several theses resulting from inquiries about the state and changes of cognition, creation, production, operation and consequences of construction. It is worth starting with engineering and technical aspects.

First of all: experience of quality construction. Already in the old days, the issue of changes in the intensity of quality was raised, which gave knowledge about nature and technology an opportunity to speak about their experience.

Secondly: the achievements of previous titans of construction $[1-3,6,10,11,13-14,17-20]$. In theories undermining the dependence of the effect on a preceding cause, the so-called principles of inertia, there is room to respect the foundations of theory and design solutions as an achievement leading to current well-being, even if at the beginning the only construction was chaos. Today, intelligent development (as defined by the EU) is based on the knowledge and innovation.

Third - where does the construction begin and where does it end? Distinguish the system, protection zone and surroundings. The merit of the current state of science is the ability to formulate a conclusion that it is not only the result of critical reflection on the existing achievements of construction, but also complies with applicable methodological principles - where there is resistance to the natural environment, operation, interaction of machinery, equipment and structures must be programmed in the construction, so that it lasts for some time, while duration of this action depends primarily on the natural culture (absorbability) of the environment and quality of the construction (compactness, environmental flexibility).

Fourth - morality of the constructor, i.e. creativity of the designer resulting from culture (engineering and technical, social), theory and construction of buildings, machines. Criticism of relationship theory in realistic terms and the statement that apart from substance and quality no Aristotelian categories have correlates in reality, led to the elimination of many traditional concepts of construction, as well as tasks and problems of construction. There are no structural authorities different from it, and there is no movement that is not identical to the operation of the structure. The law on the proportionality of loads and deformations (Hooke's law, 1660) applies equally to the element of machine construction as well as to the element of natural environment - from which the element of machinery was created. The constructor's awareness is the clarity and unambiguity of the word "construction".

Experience, achievements, construction limits and morality of the constructor are sets of abstractions; they concern engineering and technical objects as well as primary goods. The equivalence of technology and nature is clearly felt in the city. A good example is car exhaust, which organically binds vehicles to people, buildings and themselves. The exhaust gas makes breathing difficult, penetrates the clothes and walls of luxury buildings, is absorbed by plants, animals, people, and finally goes back to the car's power systems and is once again burned. The design states depend on its transformation, e.g. internal combustion engine is lubricated with oil and filings - an admixture of the product of its components wear.

This belief contributes to the author's last assumption: that the processing of any life, structure and composition of the work would take place on the basis of such total calculations and reviews, so common to be sure that nothing was left out in life, construction, environment, and preferably in the whole environment or society.

Space and natural environment are a beautiful, harmonious order. They meet the optimization criteria: optimal load, material, optimal stability and optimal ratios of related quantities. By limiting the cosmos to the natural environment, one can find an area of analysis that confirms its compactness and compositional unity a design recognition area, which also takes into account the structure of a building or machine under consideration.

Construction of machinery and the environment must not be disjoint. Creation of these important and complex structures must be based on construction principles, and should be included in the new, fourth - environmental constructional feature. The environmental constructional feature will include: environmental resources, action potentials, consequences of manufacturing, operation and decommissioning of the structural element: material, geometric, and dynamic consequences, including resource consumption, action potentials, waste, soil eutrophication and carcinogenicity in the environment.

Methodological doubts are raised by the fourth group of constructional features of technical measures - due to environmental protection during manufacture, use and disposal. There is no description of so-called environmental dimensions and tolerances. How to create a construction record taking into account the proposed fourth group of design features: resources, potentials and harmfulness?

The new content introduces design and construction chaos and serious errors in the design and construction of technical measures. For example: geometrical features are described by the geometrical form and geometrical dimensions, while the acceptable distribution of external structures is described by: dimensional tolerances, surface roughness as well as shape and position tolerances. The fourth group of (environmental) constructional features describes traits, not properties. Properties are selected, while traits are the basis for 
assessment and form a set of criteria, due to which structural features are selected, e.g. geometric traits and plastic features of wind turbine rotor blades. It is wrong to use the term "constructional element", because the element is concrete, and construction is an abstract.

Consumption of resources consists in the permissible loss of strength resources, geometric and dynamic features of the structure [5] - the structure was once developed and recorded in the construction documentation, and this one does not change. However, the characteristics of the element change as a result of wear or aging, etc.

\section{Environmental constructional feature of machines}

Construction describes structures and states of the future technical means [2, 6], it does not describe changes in the structure, the consequences of its operation, storage and recycling for the future machine. It is well known that the construction, as the reason for the existence of a machine, does not disappear after commissioning and operation until liquidation (table).

If the constructional feature is identified with the Aristotelian cause of existence (table), then on the one hand it will have the: primary (at the environmental level), functional (at the technical system level) and secondary character (associated with termination of the first existence and return to the environment); and on the other - clear signs of geometrical, material, dynamic and environmental features, also in the primary, functional and secondary approach.

TABLE. Primary, functional and secondary causes of the structural element

\begin{tabular}{|c|c|c|c|c|}
\hline No. & Cause & Primary & Functional & Secondary \\
\hline 1 & Geometric & $\begin{array}{c}\text { Geometric form } \\
\text { of the natural environment } \\
\text { consumed per element }\end{array}$ & $\begin{array}{c}\text { Form, dimension } \\
\text { and geometric tolerance } \\
\text { of the element }\end{array}$ & $\begin{array}{c}\text { Geometric form } \\
\text { of waste }\end{array}$ \\
\hline 2 & Material & $\begin{array}{c}\text { Internal structure } \\
\text { of the natural environment } \\
\text { material }\end{array}$ & $\begin{array}{c}\text { Form, dimension } \\
\text { and material tolerance } \\
\text { of the element }\end{array}$ & $\begin{array}{c}\text { Internal structure } \\
\text { of waste }\end{array}$ \\
\hline 3 & $\begin{array}{c}\text { Dynamic, } \\
\text { efficient }\end{array}$ & $\begin{array}{c}\text { Loads and unloading } \\
\text { of the environment } \\
\text { due to the disappearance } \\
\text { of form and matter }\end{array}$ & $\begin{array}{c}\text { Form, dimension } \\
\text { and tolerance of assembly } \\
\text { and functional loads } \\
\text { of the element }\end{array}$ & Waste load \\
\hline Environmental & $\begin{array}{c}\text { Resources, environmental } \\
\text { potentials consumed } \\
\text { and harmfulness } \\
\text { to the element }\end{array}$ & $\begin{array}{c}\text { Form, dimension } \\
\text { and tolerance of resources, } \\
\text { reliability potentials } \\
\text { and harmfulness } \\
\text { of the element }\end{array}$ & $\begin{array}{c}\text { Resources, } \\
\text { potentials and } \\
\text { environmental } \\
\text { harmfulness } \\
\text { of waste }\end{array}$ \\
\hline
\end{tabular}

The authors of works $[10,20]$ undertake this aspect of construction, similarly in $[4,5,7-9,12,15,16]$, but they do not formulate the essence of the environmental constructional feature. Since the construction during the operation of the machine does not disappear, it can be said that as an abstraction "is", its features should describe the structures, states and changes in the machine and the environment.

These states - geometric, material and dynamic transformations - can be partially calculated on the basis of known definitions of constructional features, introducing minor additions. Modern construction support systems, e.g. Solid Edge [15], calculate the effects and characteristics of the consequences in the machine's life cycle [9], but they do not implement it on the basis of the definition of the fourth, environmental constructional feature.

There are three basic constructional features:

$$
\begin{gathered}
C K=C_{\mathrm{g}} \cup C_{\mathrm{m}} \cup C_{\mathrm{d}} \\
C K=C_{\mathrm{g}} \cup C_{\mathrm{m}} \cup C_{\mathrm{d}}=\mathrm{f}\left\{\begin{array}{l}
\Pi_{\mathrm{g}} \cup W_{\mathrm{g}} \cup T_{\mathrm{g}} \\
\Pi_{\mathrm{m}} \cup W_{\mathrm{m}} \cup T_{\mathrm{m}} \\
\Pi_{\mathrm{d}} \cup W_{\mathrm{d}} \cup T_{\mathrm{d}}
\end{array}\right\}
\end{gathered}
$$


after introducing minor additions, it is $[2,5,6,19,20]$ :

- geometrical features $\left(\boldsymbol{C}_{\mathrm{g}}=\mathbf{f}\left(\boldsymbol{\Pi}_{\mathrm{g}} \cup \boldsymbol{W}_{\mathrm{g}} \cup \boldsymbol{T}_{\mathrm{g}}\right)\right)$, determined by the geometrical form, dimension and workmanship tolerance, being a necessary and sufficient condition for manufacturers undertaking the implementation of the geometrical form of the product according to the intended structure (example: external structure of a wind turbine blade); also determined by the geometric form, dimension and tolerance of changes, geometric consequences in the environment for the preparation and implementation of the object (e.g. blades);

- material features $\left(C_{\mathrm{m}}=\mathbf{f}\left(\Pi_{\mathrm{m}} \cup \boldsymbol{W}_{\mathrm{m}} \cup \boldsymbol{T}_{\mathrm{m}}\right)\right)$, determined by the permissible properties of the construction material and its internal structure (example: material, from which the blade will be made, selection of materials); also determined by the environmental energy and heat consumption for obtaining permissible (optimal) material properties of the construction material and its internal structure;

- dynamic features $\left(\boldsymbol{C}_{\mathrm{d}}=\mathbf{f}\left(\boldsymbol{\Pi}_{\mathrm{d}} \cup \boldsymbol{W}_{\mathrm{d}} \cup \boldsymbol{T}_{\mathrm{d}}\right)\right)$, determining the condition and assembly requirements, e.g. preload in bolts or springs or the degree of relative mobility of elements (examples: assembly features - force, pressure); also determining the environmental loads, power and energy states necessary for assembling components into sub-assemblies, assemblies and machines ready for operation.

Since the constructional feature is the property of a material element, which is the logical sum of its design forms, system of dimensions and tolerances, which relates to the geometric, material, dynamic and environmental constructional features of a machine element, it remains to rationally define the environmental constructional feature.

Environmental constructional feature $\left(\boldsymbol{C}_{\boldsymbol{\xi}}\right)$ is determined by:

$$
C_{\dot{s}}=\mathbf{f}\left(\Pi_{\dot{s}} \cup W_{\dot{s}} \cup T_{\dot{s}}\right)
$$

where:

- $\Pi_{\dot{s}}-$ form of material resources, action potentials, emissions and harmfulness that were used to manufacture the element and in its operation - can be realized;

- $\boldsymbol{W}_{\boldsymbol{s}}$ - dimensions and $\boldsymbol{T}_{\boldsymbol{s}}$ - tolerances of these resources, potentials, emissions and harmfulness of the object (element, sub-assembly, assembly and the whole machine structure), which are a necessary and sufficient condition for engineers undertaking the creation of a product according to the intended structure (example: dimension and tolerance used resources of the natural environment and creating from them resources of strength, initial, useful, unusable and recoverable potential; emission of vibrations, heat, exhaust gases, sewage, chips, waste, carcinogens in the potential of wind turbine blade construction); also determined by the form of material resources consumed, formal action potentials, emissions and harmfulness of their dimensions and tolerance of acceptable (or not) changes, material, formal and efficient consequences in man, environment - for all phases of the life cycle of the object.

Now, the environmentally integrated constructional features take the form:

$$
C K=C_{\mathrm{g}} \cup C_{\mathrm{m}} \cup C_{\mathrm{d}} \cup C_{\dot{\mathrm{s}}}=\mathbf{f}\left\{\begin{array}{l}
\Pi_{\mathrm{g}} \cup W_{\mathrm{g}} \cup T_{\mathrm{g}} \\
\Pi_{\mathrm{m}} \cup W_{\mathrm{m}} \cup T_{\mathrm{m}} \\
\Pi_{\mathrm{d}} \cup W_{\mathrm{d}} \cup T_{\mathrm{d}} \\
\Pi_{\dot{s}} \cup W_{\dot{s}} \cup T_{\dot{s}}
\end{array}\right\}
$$

Explanations is required relating to the concept of the environmental form of the constructional feature ( $\left.\Pi_{\dot{s}}\right)$ : resources, environmental potential, emissions and harmfulness of the construction.

It is, for example, about equipping the structure with a strength, structural resource in the construction process and using it during operation, equipping with strength properties for transferring technical loads and the natural operating environment, e.g. fatigue, corrosion, deformation, deformation of elasticity, plasticity or interelement milling. Resource consumption is the allowable loss of strength resources, geometrical and dynamic features of structures due to accumulation and load history. On the other hand, the form of the change in the constructional potential is characterized by the dynamics of changes from the initial state, through useful or useless loss, also restoration of potential, e.g. local strengthening. Emissions as a form of environmental features of a construction relate on the one hand to heat, vibration, noise of structural elements, while on the other exhaust gases, sewage, carbon dioxide, nitrogen compounds, sulfur, dust, etc. associated with its operation. Harmfulness of structural elements, e.g. emulsions, oils, greases and other construction fluids, are revealed in 
the form of harmfulness to human health, also soil eutrophication and environmental degradation as a result of the creative, manufacturing, operational and decommissioning of the structure over its life cycle.

It should be noted here that there are four basic constructional features:

$$
C K=C_{\mathrm{g}} \cup C_{\mathrm{m}} \cup C_{\mathrm{d}} \cup C_{\mathrm{s}}
$$

Quality is the decisive factor in permissible state, transformations, loss of properties, resources, potentials, emissions and harmfulness. All the arguments for the introduction of the fourth constructional feature cannot be discussed in a short engineering and technical paper. However, it is already possible to provide environmental constructional features, e.g. $\mathrm{CO}_{2}$ emissions (fig. 2).

\section{Example}

More and more often, scientific research is carried out, including determination of forms, dimensions, tolerances of environmental characteristics of machine constructions: resources and harmful potentials according to LCA (live cycle assessment) procedures. First of all, negative impact of the production, exploitation and scrapping of constructional elements on the natural environment, human health and quality of aquatic and terrestrial ecosystems are examined. Among the categories of environmental impacts affecting the life cycle of a wind turbine rotor construction (figs. 2 and 3 ) $[8,15]$, the particularly important role of processes related to the extraction of fossil fuels (5.165.5286 Pt, Pt - European Union environmental points (of one European citizen) are compatible with the SI system). Processes related to the extraction of minerals and compounds that cause climate change (532.3707 Pt), including carbon dioxide (42.54\%), 1,1,1,2-tetrafluoroethane (39.79\%) and methane (15.9\%) are also important.

Radioactive compounds $(14,9206 \mathrm{Pt})$ have the lowest environmental impact, of which radon $222(84.6 \%)$, cesium $^{137}(5.21 \%)$ and carbon $^{14}(1.81 \%)$ are distinguished primarily. For the post-utilization model of wind turbine rotor blade construction, in the form of recycling, the significant positive role of processes related to the extraction of fossil fuels is important $(-6,100 \mathrm{Pt})$. Compounds causing climate change $(-216 \mathrm{Pt})$, acidification/eutrophication $(-123 \mathrm{Pt})$, especially nitric oxide $(92.3 \%)$ and sulfur oxide $(7.76 \%)$, as well as processes related to mineral extraction $(-71 \mathrm{Pt})$, including bauxite mining $(80.6 \%)$ and iron ore $(19.4 \%)$ are also of great significance. Nevertheless, ecotoxic compounds (63.8 Pt), including lead $(66.1 \%)$, nickel $(17.4 \%)$ and zinc $(16.5 \%)$, have also significant impact.

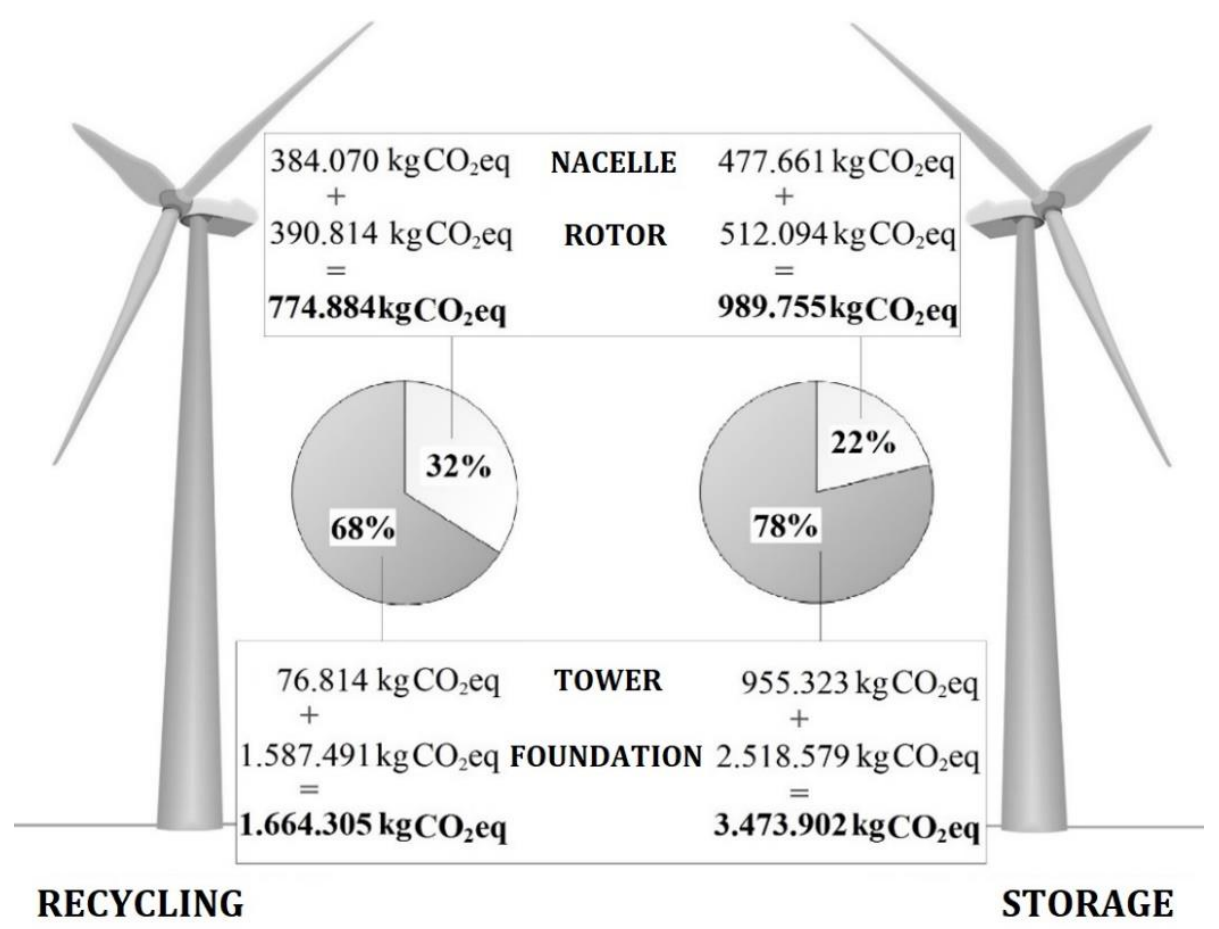

Fig. 2. Greenhouse gas emissions over the life cycle of selected wind farm components ending in recycling or storage [8] 
During the study and assessment of the life cycle impact of a high-power wind turbine rotor construction (2 MW), which ended at a landfill (fig. 3), the processes related to the extraction of fossil fuels (5,165.5286 Pt), minerals $(911.7851 \mathrm{Pt})$ and land use (235.055 Pt), especially occupation by the industrial area (33.3\%), land use II-III (23.4\%), transformation into continuous development (22.9\%), transformation into an industrial area (11\%), occupation by continuous development (3.81\%), land use III-IV (1.33\%) and land use II-IV (1.2\%), had the greatest impact on the total level of resources. Radioactive compounds had the least negative impact on resources (14.9206 Pt).

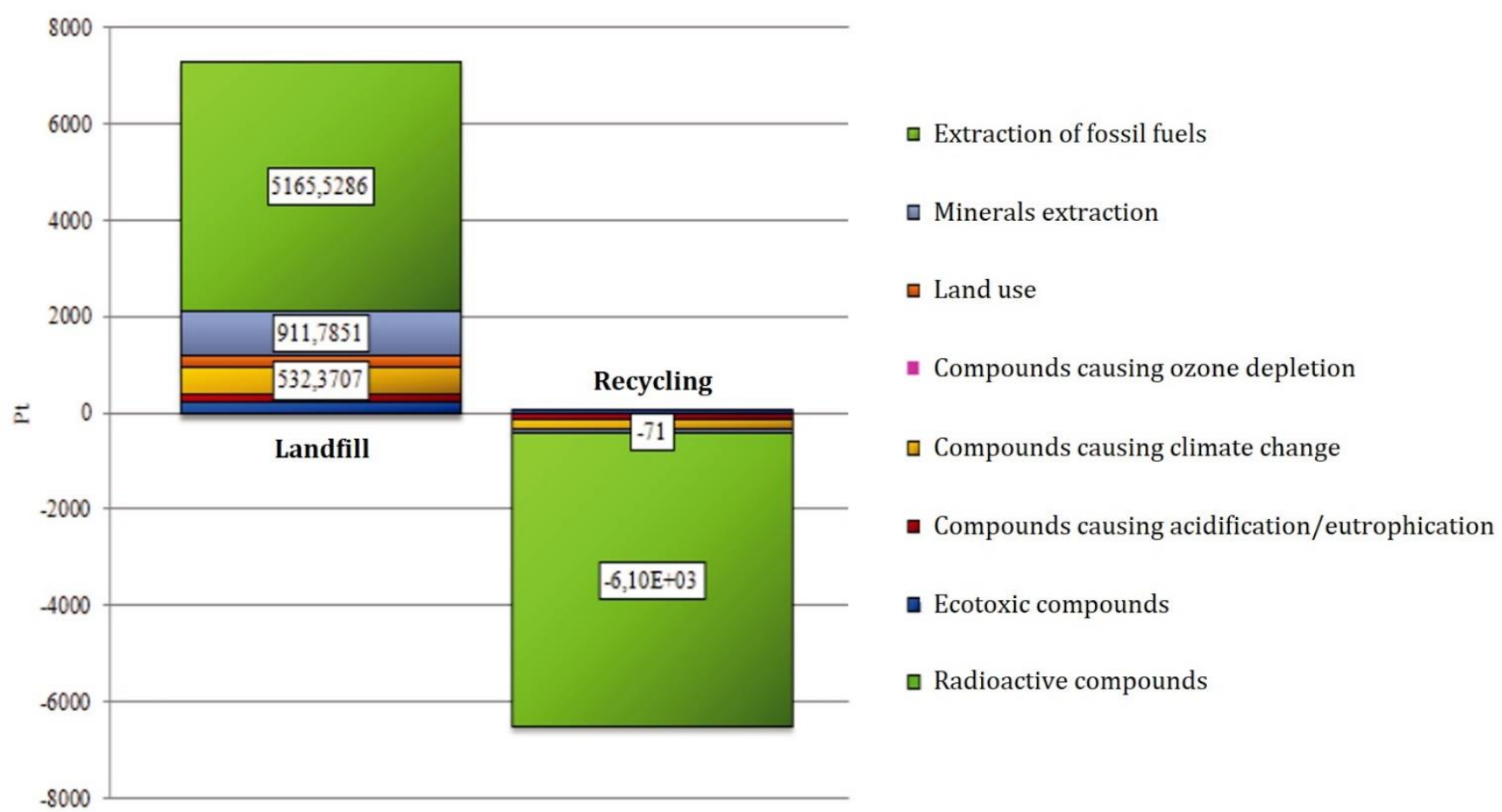

Fig. 3. Impact of the life cycle of a wind farm rotor structure including the category of environmental impacts [15]

The recycling model - as a form of the post-use development of the rotor blade construction - includes two categories of environmental impacts: extraction of fossil fuels and minerals. Extraction of fossil fuels $(-6.100 \mathrm{Pt})$ had the largest impact on the reduction of the total level of sozological resources consumption, and the lowest - extraction of minerals (-71 Pt) (fig. 3).

\section{Summary}

Opinions and research programs have existed since the Middle Ages, in which the following knowledge pillars are set: learning nature, managing nature, and improving nature as a goal of cognitive and practical activity. It is worth noting that the theoretical construction could not be constrained by any knowledge systems, and the scientific theories existing since the Middle Ages, having a relative value, can be replaced by more correct ones, corresponding to new achievements in the field of experimental knowledge and theoretical reflection. However, becoming aware of all the consequences of these assumptions for construction is the work of contemporary creators of engineering and technical sciences in the field of construction.

Adopting the position, according to which construction as a practical science, performs prognostic and technical function, thus entails the need to recognize it as empirical and inductive science at the same time. The emphasis should be put on combining these two properties together. Strategy for recognizing the states and changes in the construction of machines in technological, environmental and waste cycles after their operation, reliably built and useful for the practice of improving the environment, must start from the study of specific facts of reality, but these facts must in turn properly classify and generalize the theory of machine design and the environment.

The aim of the study was to indicate the environmental features (usability and harmlessness) of the construction and to familiarize the essence of the fourth (environmental) constructional feature of machine elements, devices and other engineering and technical objects. 
So far, when constructing, manufacturing and operating buildings and machines, one sporadically dealt with their organic compactness, compositional unity with life, selected areas and objects of the environment.

\section{Conclusions}

The aim of the study was achieved, indicating the need for an environmental approach to the usability and harmlessness of the construction in the proposal of the essence of the fourth constructional feature of machine elements, devices and other engineering and technical objects, e.g. wind turbine blades.

Geometrical, material, dynamic and environmental constructional features correspond to the external and internal structures as well as states of the product and natural environment. Machine construction as an optimal and acceptable structure and condition, in the scope of: geometry (forms), material (matter), efficiency (assembly, idle, working) and environment (resources, potentials, harmfulness), is a man-made, purposeful technical system of the environment. It is therefore obvious that it has environmental constructional features.

The goal was achieved by formulating numerous questions and answers and solving problems. The most important doubt was whether the construction of environment was governed by reasons other than engineering and technical construction. This question, on the borderline of theology, can be answered that in the environment, a change in acceptable forms, dimensions, tolerance of geometric, material and dynamic properties, and raw material resources (material, energy, information) leads to an end, causes the resource to deform, and e.g. when unrecoverable - it disappears. Exceeding the allowable (in the environment - optimal) forms, dimensions and tolerance of resources, potentials and harmfulness causes destruction or devastation of the resources of reproducible and unreproducible goods. It's hard to talk about waste here, because we live in what remains - is it a valuable resource and environmental potential?!

\section{REFERENCES}

[1] Dietrich M. i in. „Podstawy konstrukcji maszyn”. T. I. Warszawa: PWN, 1986.

[2] Dietrych J. „System i konstrukcja”. Warszawa: WNT, 1985.

[3] Dziama A. „Metodyka konstruowania maszyn”. Warszawa: PWN, 1985.

[4] Flizikowski J. „Konstrukcja rozdrabniaczy żywności”. Bydgoszcz: WU UTP, 2005.

[5] Flizikowski J. „Rozprawa o konstrukcji”. Radom: Wyd. Instytutu Techn. Eksploat., 2002.

[6] Gendarz P. „Metodologia projektowania i konstruowania Szkoły Śląskiej i jej wpływ na ukształtowanie się zasad konstruowania". KAMAG, Górnictwo Odkrywkowe. Gliwice, 2012: 49-55.

[7] Kamyk W. „Badanie i rozwój zintegrowanego układu wielotarczowego rozdrabniania ziaren kukurydzy”. Rozprawa doktorska. Bydgoszcz: UTP w Bydgoszczy, 2008.

[8] Kasner R. „Ocena korzyści i nakładów cyklu życia elektrowni wiatrowej”. Rozprawa doktorska. Poznań: PP, 2016.

[9] Kłos Z. „Środowiskowa ocena maszyn i urzq̨dzeń". Poznań: Wydawnictwa Politechniki Poznańskiej, 1998.

[10] Kocańda S., Szala J. „Podstawy obliczeń zmęczeniowych”. Warszawa: PWN, 1985.

[11] Kowalski J. „Modelowanie obiektów konstrukcyjnych w projektowaniu optymalnym”. Warszawa: WNT, 1983.

[12] Kruszelnicka W., Bałdowska-Witos P., Flizikowski J., Tomporowski A., Ropińska P., Ignaczak P. “The blowing proces of a PET bottlers". International Scientific Journal - Machines. Technologies. Materials. WEB ISSN 1314-507X; PRINT ISSN 1313-0226, 2019.

[13] Osinski Z., Wróbel J. „Teoria konstrukcji maszyn”. Warszawa: PWN, 1982.

[14] Pahl G., Beitz W. „Nauka konstruowania”. Warszawa: WNT, 1984.

[15] Piasecka I. „Badanie i ocena cyklu życia zespołów elektrowni wiatrowych”. Rozprawa doktorska. Poznań: PP, 2014.

[16] Sadkiewicz J. „Prowdrożeniowe badanie efektywności pracy wielotarczowego rozdrabniacza ziaren zbóż". Rozprawa doktorska. Bydgoszcz: UTP w Bydgoszczy, 2014.

[17] Skarbinski M., Skarbinski J. „Technologiczność konstrukcji maszyn”. Warszawa: WNT, 1982.

[18] Tarnowski W. „Podstawy projektowania technicznego”. Warszawa: WNT, 1997.

[19] P.Wr., https://notatek.pl/wyklad-cechy-konstrukcyjne-zasady-konstrukcji (dostęp: 26.08.2019).

[20] Żebrowski $\quad$ M., https://kmpkm.zut.edu.pl/pub/Podstawy_Konstrukcji_Maszyn/PKM_wyklady\%20(M.Zebrowski)/Zajecia \%20projektowe/1.Teoria\%20proj.pdf (access: 26.08.2019).

[21] https://www.lmwindpower.com/en/stories-and-press/stories/news-from-lm-places/lm-windpower-manufactures-the-worlds-first-wind-turbine-blade-beyond-100-meters (access: 11.11.2019). 